\title{
Stony corals (Anthozoa: Scleractinia) of Burdwood Bank and neighbouring areas, SW Atlantic Ocean
}

\author{
Laura Schejter ${ }^{1,2}$, Claudia S. Bremec ${ }^{1}$ \\ ${ }^{1}$ Instituto de Investigaciones Marinas y Costeras, Consejo Nacional de Investigaciones Científicas y Técnicas (IIMyC- \\ CONICET), Argentina. \\ (LS) (Corresponding author) E-mail: schejter@inidep.edu.ar. ORCID iD: https://orcid.org/0000-0001-5443-4048 \\ (CB) E-mail: claudiasilviabremec@gmail.com. ORCID iD: https://orcid.org/0000-0001-5342-7997 \\ ${ }^{2}$ Instituto Nacional de Investigación y Desarrollo Pesquero (INIDEP). Paseo Victoria Ocampo 1, 7600, Mar del Plata, \\ Argentina.
}

\begin{abstract}
Summary: The presence of ten species of stony corals was recorded at a total of 19 out of 48 sampling stations at Burdwood Bank and neighbouring areas. Scleractinians were recorded only at three stations inside the marine protected area (MPA) Namuncurá I, while the majority of them were recorded deeper than $200 \mathrm{~m}$. Burdwood Bank slope (MPA Namuncurá II + NW slope) was the richest sub-area, with ten species recorded in the present study and another two species mentioned from the literature. For the majority of the species the results here presented represent the only available data in the study area after 50 years (or more), comprising updates of latitudinal and bathymetric ranges. Stony corals were recorded as basibionts of a variety of organisms. Mainly dead skeletons were found providing a suitable settlement substrate for sessile species such as primnoid corals. The presence of a high richness of stony corals on the southern slope of Burdwood Bank, as components of the marine animal forests recorded, also supported the conservation efforts made to create the new MPA named "Namuncurál Burdwood Bank II" in this region.
\end{abstract}

Keywords: conservation; cold-water corals; Argentina; MPA; Namuncurá/Burdwood Bank; biodiversity.

Corales de piedra (Anthozoa: Scleractinia) del banco Burdwood y áreas vecinas, océano Atlántico SO

Resumen: Diez especies de corales fueron registradas en 19 sitios (de un total de 48 estaciones de muestreo) en el banco Burdwood y áreas vecinas. Los corales escleractínidos fueron detectados solamente en tres estaciones dentro del Área Marina Protegida (AMP) Namuncurá I, ya que la mayoría de ellos se encuentran usualmente a más de $200 \mathrm{~m}$. de profundidad. El talud del banco Burdwood (AMP Namuncurá II + talud NO) fue la sub-área de mayor riqueza, contando con diez especies registradas en este estudio, más otras dos tomadas de fuentes bibliográficas. Los resultados presentados en este trabajo representan los registros de corales escleractínidos más recientes y los únicos en 50 años (o más) para la región, y contemplan, además actualizaciones latitudinales y batimétricas para algunas especies. Las especies de estos corales registradas fueron basibiontes de una gran variedad de organismos. En este sentido, principalmente los esqueletos muertos proveyeron de un sustrato de asentamiento adecuado a especies sésiles tales como corales primnoideos. La presencia de una alta riqueza de estos corales en el talud sur del banco Burdwood como componentes de los bosques animales registrados, contribuyó con los esfuerzos de conservación realizados en la zona y que culminaron con la creación del AMP "Namuncurá/ banco Burdwood II".

Palabras clave: conservación; corales de aguas frías; Argentina; AMP; Namuncurá/banco Burdwood; biodiversidad.

Citation/Como citar este artículo: Schejter L., Bremec C.S. 2019. Stony corals (Anthozoa: Scleractinia) of Burdwood Bank and neighbouring areas, SW Atlantic Ocean. Sci. Mar. 83(3): 247-260. https://doi.org/10.3989/scimar.04863.10A

Editor: R. Sardà.

Received: September 20, 2018. Accepted: June 19, 2019. Published: July 14, 2019.

Copyright: (C) 2019 CSIC. This is an open-access article distributed under the terms of the Creative Commons Attribution 4.0 International (CC BY 4.0) License.

\section{INTRODUCTION}

In 2013, Argentina created a marine protected area (MPA) at Burdwood Bank, defined below the $200 \mathrm{~m}$ isobath. This MPA, named "Namuncurá" (here mentioned as "Namuncurá I", Fig. 1) and created by National Law $\mathrm{N}^{\circ} 26875$, was the first open-sea (non-coastal) MPA of the country. This MPA of about $28000 \mathrm{~km}^{2}$ reaches between 50 and $200 \mathrm{~m}$ depth in a vertically homogeneous dynamic environment of sub-Antarctic waters, ranging 
seasonally from 4 to $9^{\circ} \mathrm{C}$ and with a mean salinity of 34 (Piola and Gordon 1989, Guerrero et al. 1999). The MPA was established following international criteria of vulnerability (i.e. FAO 2009, Auster et al. 2011, Portela et al. 2012). The presence of a high biomass of sessile taxa, long-living species and very slow recovery times of the benthic community after a perturbation event (Falabella et al. 2017) was also assumed. Initial results of the Argentinean expeditions revealed that the plateau showed heterogeneous benthic communities where sponges and bryozoans played important roles in terms of biodiversity (Schejter et al. 2016a, 2017a, Bremec et al. 2017), while cnidarians-specifically corals - were probably important components in terms of biomass, but mainly at the slope of the bank (Schejter et al. 2016a, 2018a) and hence outside the MPA.

In recent years several research cruises have been carried out, following the MPA Management Plan and supported by Argentinean policy, aiming to provide specific and interdisciplinary information regarding the oceanography, geology, biology and ecology of the organisms inhabiting this area, and its relation with other surrounding sub-Antarctic and Patagonian regions. The provision of an updated inventory of the organisms recorded inside the MPA and in the nearby regions was one of the main goals of the cruises. Among the novelties, new species for science have been described (i.e. Schejter et al. 2017b, López Gappa et al. 2017, Güller and Zelaya 2017) and many more are undergoing the description process. Distributional ranges of several recorded species have also been updated (Fraysse et al. 2018, Schejter et al. 2018b). Additionally, data recorded during these cruises showed that important benthic communities and oceanographic and ecological processes take place outside the Namuncurá I, on the slopes of Burdwood Bank, deeper than $200 \mathrm{~m}$ (FCMPAI 2018, Schejter et al. 2018a). Cold-water corals forming animal forests were recently recorded on the southern and northwestern slopes of Burdwood Bank (Schejter et al. 2018a, b). In these particular ecosystems, substrate, refuge and protection for myriad organisms may also be provided by cnidarians and other habitat-forming species, as mentioned by Buhl-Mortensen et al. (2017) and specifically noted on Burdwood Bank by Martin Sirito (2019). Following all this evidence (Falabella et al. 2017, FCMPAI 2018), a new MPA named "Namuncurá/Burdwood Bank II" (here designated as "Namuncurá II") was created in December 2018 (National Law 27490, Fig. 1), on the southern slope of Burdwood Bank, starting at the 200 $\mathrm{m}$ isobath and reaching $4000 \mathrm{~m}$. This new MPA preserves about $32000 \mathrm{~km}^{2}$ adjacent to Namuncurá I.

Data on stony corals (Scleractinia) provided by this study were part of the information used to support the importance of the southern slope of Burdwood Bank, where the new MPA Namuncurá II was created. Here we provide and update data on scleractinian corals and their distribution at Burdwood Bank and the surrounding Patagonian area. We also provide information of associated species (i.e. epibionts and basibionts) in order to characterize their role in increasing the biodiversity of the ecosystem, considering that scleractinians are components of the coral gardens and other types of the marine animal forests recorded on the slopes of the bank. Finally, we discuss and provide supplementary data regarding scleractinians' distribution in the study area from bibliographic sources.

\section{MATERIALS AND METHODS}

Namuncurá I, Namuncurá II, Burdwood Bank NW slope, the Neighbouring Deep Region, Staten Island and shelf waters off Tierra del Fuego, Argentina, were sampled during two research cruises onboard the RV Puerto Deseado (March 26 - April 25, 2016; April 22 - May 12, 2017). A total of 48 stations were sampled for the acquisition of benthic fauna (Fig. 1, Table 1). A bottom trawl of $6 \mathrm{~m}$ total length, $50 \mathrm{~mm}$ mesh size and $10 \mathrm{~mm}$ mesh size at the cod end was the main sampler used in the study. However, additional material was also collected at several stations using a bigger trawl device and/or dredges at the same stations. For georeferencing data we indicate the station number, but also a second number in brackets that corresponds to the exact location of the haul at the mentioned station (Table 1). Basic oceanographic data (temperature and salinity) is also provided for each station. A description of the main faunistic groups recorded at each station can be found in the cruise reports (Schejter et al. $2016 \mathrm{~b}, 2017 \mathrm{c}$ ), and information of benthic community composition of sites below $200 \mathrm{~m}$ depth can also be found in Schejter et al. (2018a). We kept the original station denomination to facilitate exchange of results with other faunistic studies that are underway.

Scleractinian specimens were separated at all the stations from total catch and were photographed, labelled, preserved and transported to the Benthos Laboratory (Instituto Nacional de Investigación y Desarrollo Pesquero, Argentina). At some stations, catches were very abundant and it was not possible to inspect the total catch. Also, at some stations, corals were partially subsampled for other studies. In consequence, it was not possible to estimate species densities in the present study, although qualitative reference data (i.e. frequent, common, abundant, etc.) are given.

The morphological terminology used in this study is defined and illustrated in Cairns and Kitahara (2012). The main bibliographic sources employed for the taxonomic identification were Zibrowius (1974), Cairns (1979, 1990, 1982), Cairns and Polonio (2013), Cairns and Kitahara (2012), Schejter and Bremec (2015), and Schejter et al. (2015, 2016c).

The following abbreviations were used in the text: BBB 2016: Expedition to Burdwood Bank, RV Puerto Deseado, between 26 March and 25 April 2016.

PD BB 2017: Expedition to Burdwood Bank, RV Puerto Deseado, between 22 April and 12 May 2017. St: station/site

CD: calicular diameter

$\mathrm{CH}$ : corallum height

PD: pedicel diameter

Voucher specimens of all the recorded species and from the majority of the sampled sites have been deposited at the Museo Argentino de Ciencias Natu- 


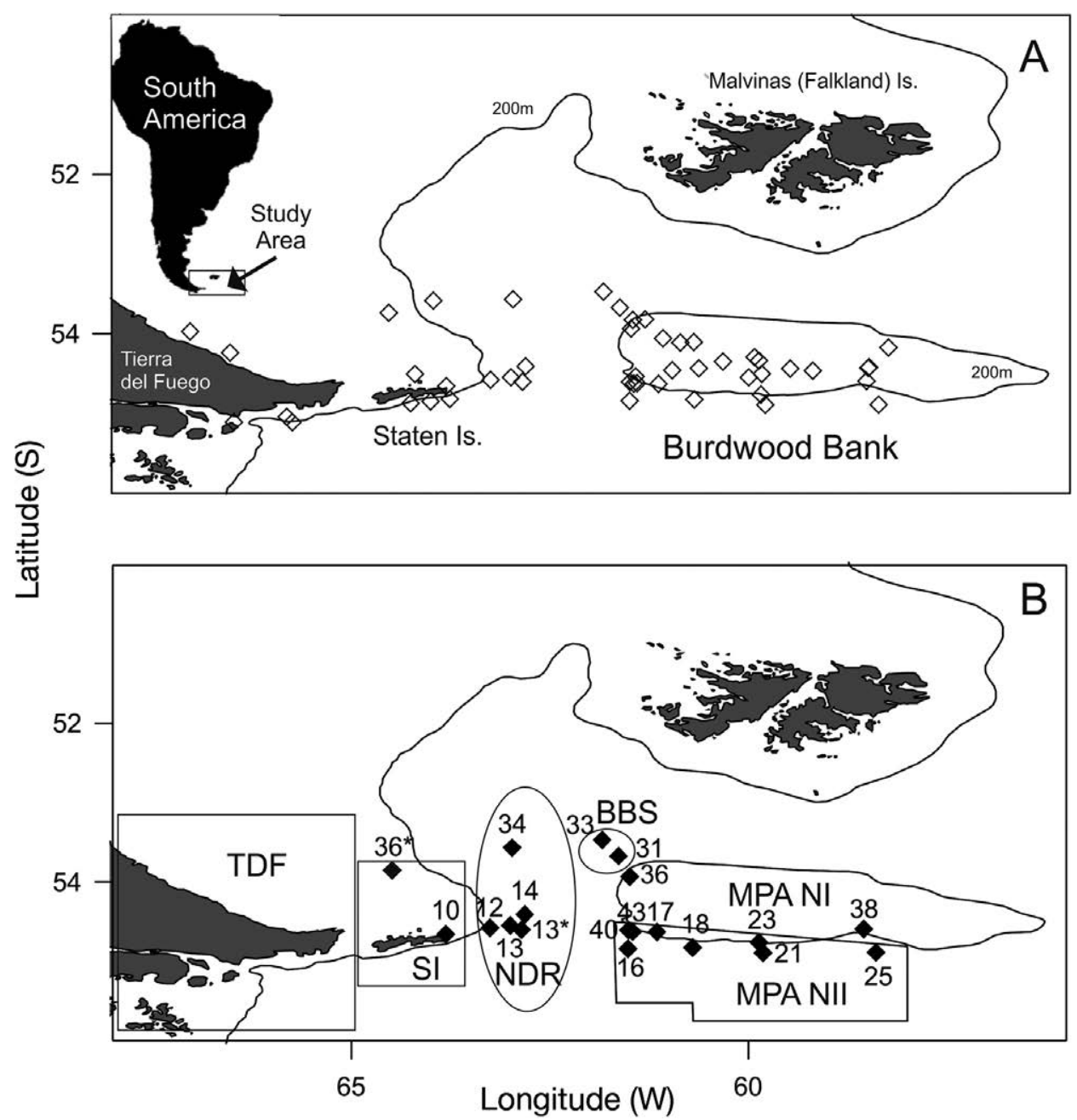

Fig. 1. - Study area. A. Total sampling stations performed during 2017 and 2018 cruises. B. Stations where stony corals were recorded. Subareas: TDF, Tierra del Fuego; SI, Staten Island; NDR, Neighbouring Deep Region; MPA NI, marine protected area Namuncurá I; MPA NII, marine protected area Namuncurá II; BBS, Burdwood Bank NW slope.

rales "Bernardino Rivadavia" (MACN), Buenos Aires, Argentina.

\section{RESULTS}

The presence of scleractinians was recorded at 19 of the 48 sampled stations (Figs 1, 2; Table 1). A total of 1022 individuals were studied and $92 \%$ of the specimens were identified to species level. The remaining specimens were juveniles or broken individuals that only allowed identification to genus level (all of them belong to Flabellum). Of the studied samples, $75 \%$ were living specimens. Ten solitary scleractinian species were registered at the studied sites (Figs 2, 3); no colonial species were recorded. The identified species are listed below, with some remarks and notes on distribution and associated fauna.

Phylum CNIDARIA Verrill, 1865

Class Anthozoa Ehrenberg, 1834

Subclass Hexacorallia Haeckel, 1896

Order Scleractinia Bourne, 1900

Family Dendrophyllidae Gray, 1847
Genus Balanophyllia Wood, 1844

Balanophyllia malouinensis Squires, 1961

(Figs 2B, 3A, B, 4A-F, 5B, F)

Material examined. BBB 2016: St. 12 (212) 13 specimens, St. 13 (172) 62 specimens, St. 13 (175) 2 specimens, St. 16 (334) 11 specimens, St. 18 (266) 34 specimens, St. 18 (267) 17 specimens, St. 21 (239) 11 specimens, St. 21 (245) 1 specimen, St 23 (226) 1 specimen, St. 23 (228) 5 specimens, St. 23 (233) 3 specimens, St. 25 (37) 1 specimen, St. 36 (307) 3 specimens. PD BB 2017: St. 13 (103) 55 specimens, St. 14 (118) 57 specimens, St. 16 (131) 47 specimens, St. 31 (269) 28 specimens, St. 33 (256) 5 specimens, St. 34 (249) 37 specimens, St. 43 (326) 18 specimens (MACN-In 41666, MACNIn 41667, MACN-In 41668, MACN-In 41669, MACN-In 41670, MACN-In 41671, MACN-In 41672, MACN-In 41673).

Main measurements. $\mathrm{CH}$ ranged between 4 and 55 $\mathrm{mm}$; CD between $4 \times 4 \mathrm{~mm}$ and $19 \times 21 \mathrm{~mm}$ and PD between 3 and $7 \mathrm{~mm}$.

Distribution. Off Tierra del Fuego, Malvinas (Falkland) Islands and Scotia Ridge between Burdwood Bank and South Georgias Is. (75-780 m), Drake Passage off cape Horn (494-1137 m), off Isla Desolación, Chile, 53오 (132 m) (Cairns 1982, Cairns et al. 2005). 
Table 1. - Date, location and depth of the stations sampled during this study. Temperature and salinity data were taken from Cruise Reports (see Schejter et al. 2016c, 2017c). \# estimation from a nearby station; * data corresponding to a depth of $\sim 350 \mathrm{~m}$; na, data not available.

\begin{tabular}{|c|c|c|c|c|c|c|c|c|c|c|c|}
\hline Cruise & Date $(\mathrm{d} / \mathrm{m} / \mathrm{y})$ & & ation & Sub-area & Lat $\left({ }^{\circ} \mathrm{S}\right)$ & Long $\left({ }^{\circ} \mathrm{W}\right)$ & $\begin{array}{l}\text { Depth } \\
\text { (m) }\end{array}$ & $\begin{array}{l}\text { Presence of } \\
\text { stony corals }\end{array}$ & Sampler & $\begin{array}{l}\text { Bottom T } \\
\left({ }^{\circ} \mathrm{C}\right)\end{array}$ & $\begin{array}{l}\text { Bottom } \\
\text { Salinity }\end{array}$ \\
\hline BBB 16 & 03/04/2016 & 4 & (107) & $\mathrm{TDF}$ & 55.104333 & 66.469 & 71 & & trawl & 9.01 & 33.34 \\
\hline BBB 16 & $06 / 04 / 2016$ & 5 & (127) & TDF & 55.0375 & 65.806733 & 114 & & trawl & 8.83 & 33.31 \\
\hline BBB 16 & $22 / 04 / 2016$ & 11 & $(38)$ & SI & 54.501817 & 64.2016 & 107 & & trawl & 7.67 & 33.54 \\
\hline BBB 16 & $11 / 04 / 2016$ & 12 & (211) & NDS & 54.5745 & 63.254767 & 372 & & trawl & 4.63 & 34.15 \\
\hline BBB 16 & $11 / 04 / 2016$ & 12 & (212) & NDS & 54.549467 & 63.201083 & 416 & $\mathrm{x}$ & dredge & 4.63 & 34.15 \\
\hline BBB 16 & 09/04/2016 & 13 & (172) & NDS & 54.598367 & 62.855317 & 608 & $\mathrm{X}$ & trawl & 3.78 & 34.23 \\
\hline BBB 16 & 09/04/2016 & 13 & (175) & NDS & 54.6965 & 62.786683 & 681 & $\mathrm{X}$ & big trawl & 3.78 & 34.23 \\
\hline BBB 16 & $20 / 04 / 2016$ & 16 & (334) & MPA NII & 54.836767 & 61.5137 & 1000 & $\mathrm{x}$ & dredge & 3.38 & 34.35 \\
\hline BBB 16 & $15 / 04 / 2016$ & 17 & (282) & MPA NII & 54.624733 & 61.152533 & 202 & $\mathrm{x}$ & trawl & 6.33 & 34.12 \\
\hline BBB 16 & $13 / 04 / 2016$ & 18 & (266) & MPA NII & 54.820983 & 60.703583 & 607 & $\mathrm{X}$ & trawl & 4.23 & 34.20 \\
\hline BBB 16 & $13 / 04 / 2016$ & 18 & (267) & MPA NII & 54.811417 & 60.721883 & 553 & $\mathrm{x}$ & dredge & 4.23 & 34.20 \\
\hline BBB 16 & $13 / 04 / 2016$ & 18 & (268) & MPA NII & 54.824283 & 60.688467 & 608 & $\mathrm{X}$ & big trawl & 4.23 & 34.20 \\
\hline BBB 16 & $13 / 04 / 2016$ & 21 & (239) & MPA NII & 54.886967 & 59.815 & 785 & $\mathrm{X}$ & trawl & 4.13 & 34.17 \\
\hline BBB 16 & $13 / 04 / 2016$ & 21 & $(245)$ & MPA NII & 54.890567 & 59.809833 & 767 & $\mathrm{X}$ & big trawl & 4.13 & 34.17 \\
\hline BBB 16 & $13 / 04 / 2016$ & 23 & (226) & MPA NI & 54.7596 & 59.868917 & 182 & $\mathrm{x}$ & trawl & 5.81 & 34.04 \\
\hline BBB 16 & $13 / 04 / 2016$ & 23 & (228) & MPA NI & 54.759267 & 59.886617 & 187 & $\mathrm{X}$ & dredge & 5.81 & 34.07 \\
\hline BBB 16 & $13 / 04 / 2016$ & 23 & (233) & MPA NI & 54.747 & 59.947633 & 177 & $\mathrm{X}$ & big trawl & 5.81 & 34.07 \\
\hline BBB 16 & $29 / 03 / 2016$ & 25 & $(37)$ & MPA NII & 54.885017 & 58.395983 & 451 & $\mathrm{X}$ & dredge & 4.34 & 34.12 \\
\hline BBB 16 & $29 / 03 / 2016$ & 26 & (27) & MPA NI & 54.4158 & 58.515167 & 137 & & trawl & 6.16 & 34.02 \\
\hline BBB 16 & $28 / 03 / 2016$ & 27 & (11) & MPA NI & 54.16775 & 58.272617 & 100 & & trawl & 6.37 & 34.03 \\
\hline BBB 16 & $30 / 03 / 2016$ & 28 & $(52)$ & MPA NI & 54.459383 & 59.220167 & 128 & & trawl & 6.32 & 34.00 \\
\hline BBB 16 & $10 / 04 / 2016$ & 30 & (184) & MPA NI & 54.288483 & 59.950783 & 96 & & trawl & 6.67 & 34.05 \\
\hline BBB 16 & $10 / 04 / 2016$ & 31 & (197) & MPA NI & 54.499367 & 59.858867 & 109 & & trawl & 6.33 & 34.07 \\
\hline BBB 16 & $30 / 03 / 2016$ & 32 & $(77)$ & MPA NI & 54.543317 & 60.021317 & 98 & & trawl & na & 34.05 \\
\hline BBB 16 & 08/04/2016 & 33 & (159) & MPA NI & 54.429533 & 60.647717 & 101 & & trawl & 6.54 & 34.07 \\
\hline BBB 16 & 07/04/2016 & 34 & (146) & MPA NI & 54.4543 & 60.980333 & 100 & & trawl & 6.49 & 34.06 \\
\hline BBB 16 & $31 / 03 / 2016$ & 35 & $(89)$ & MPA NI & 54.531983 & 61.438517 & 125 & & trawl & 6.80 & 34.05 \\
\hline BBB 16 & $19 / 04 / 2016$ & 36 & (306) & MPA NI & 53.929883 & 61.4956 & 185 & $\mathrm{x}$ & trawl & 6.29 & 34.07 \\
\hline BBB 16 & $19 / 04 / 2016$ & 36 & (307) & MPA NI & 53.929333 & 61.545217 & 196 & $\mathrm{X}$ & dredge & 6.29 & 34.07 \\
\hline BBB 16 & $19 / 04 / 2016$ & 36 & (310) & MPA NI & 53.931983 & 61.532133 & 194 & $\mathrm{X}$ & big trawl & 6.29 & 34.07 \\
\hline BBB 16 & $29 / 03 / 2016$ & 38 & (39) & MPA NI & 54.588733 & 58.547217 & 135 & $\mathrm{X}$ & trawl & $6.16 \#$ & 34.03 \# \\
\hline BBB 16 & 06/04/2016 & 39 & (140) & SI & 54.844067 & 64.0069 & 159 & & trawl & 3.50 & 33.52 \\
\hline BBB 16 & $19 / 04 / 2016$ & 40 & (320) & MPA NII & 54.616767 & 61.420833 & 415 & & trawl & 4.19 & 34.23 \\
\hline PD BB 17 & $23 / 04 / 2017$ & 5 & (9) & TDF & 55.106669 & 65.736681 & 263 & & trawl & 6.97 & 33.90 \\
\hline PD BB 17 & $24 / 04 / 2017$ & 9 & $(50)$ & SI & 54.868351 & 64.256672 & 151 & & trawl & 8.87 & 33.47 \\
\hline PD BB 17 & $11 / 05 / 2017$ & 10 & (349) & SI & 54.653346 & 63.810016 & 143 & $\mathrm{x}$ & trawl & 8.06 & 33.56 \\
\hline PD BB 17 & $24 / 04 / 2017$ & 11 & $(36)$ & SI & 54.81335 & 63.765015 & 278 & & trawl & 5.60 & 34.09 \\
\hline PD BB 17 & $27 / 04 / 2017$ & $13^{*}$ & (103) & NDS & 54.543344 & 63 & 460 & $\mathrm{x}$ & trawl & 5.01 & 34.16 \\
\hline PD BB 17 & $28 / 04 / 2017$ & 14 & (118) & NDS & 54.405008 & 62.816683 & 483 & $\mathrm{X}$ & trawl & 4.85 & 34.18 \\
\hline PD BB 17 & $28 / 04 / 2017$ & 16 & (131) & MPA NII & 54.600012 & 61.51001 & 294 & $\mathrm{X}$ & trawl & 5.47 & 34.11 \\
\hline PD BB 17 & $30 / 04 / 2017$ & 21 & (157) & MPA NI & 54.425009 & 58.525011 & 138 & & trawl & 6.75 & 33.95 \\
\hline PD BB 17 & $01 / 05 / 2017$ & 23 & (173) & MPA NI & 54.433342 & 59.503343 & 91 & & trawl & 7.08 & 33.86 \\
\hline PD BB 17 & $01 / 05 / 2017$ & 24 & (184) & MPA NI & 54.33334 & 59.895018 & 97 & & trawl & 7.02 & 33.88 \\
\hline PD BB 17 & $09 / 05 / 2017$ & 25 & (304) & MPA NI & 54.345007 & 60.345007 & 104 & & trawl & 6.87 & 33.89 \\
\hline PD BB 17 & 09/05/2017 & 26 & (317) & MPA NI & 54.100002 & 60.710014 & 120 & & trawl & 6.87 & 33.92 \\
\hline PD BB 17 & 09/05/2017 & 27 & (326) & MPA NI & 54.106669 & 60.878351 & 128 & & trawl & 7.15 & 33.95 \\
\hline PD BB 17 & $08 / 05 / 2017$ & 28 & (287) & MPA NI & 54.053334 & 61.095002 & 140 & & trawl & 7.23 & 33.95 \\
\hline PD BB 17 & 08/05/2017 & 29 & (283) & MPA NI & 53.815016 & 61.320006 & 197 & & trawl & 6.40 & 33.97 \\
\hline PD BB 17 & $08 / 05 / 2017$ & 30 & (273) & BBS & 53.821683 & 61.473343 & 209 & & trawl & 5.47 & 34.06 \\
\hline PD BB 17 & $07 / 05 / 2017$ & 31 & (269) & BBS & 53.66668 & 61.636679 & 642 & $\mathrm{x}$ & trawl & $4.85 *$ & $34.09 *$ \\
\hline PD BB 17 & 07/05/2017 & 33 & (256) & BBS & 53.466676 & 61.841684 & 595 & $\mathrm{X}$ & trawl & $4.95 *$ & $34.08 *$ \\
\hline PD BB 17 & $07 / 05 / 2017$ & 34 & (249) & NDS & 53.563345 & 62.973353 & 516 & $\mathrm{x}$ & trawl & 4.94 & 34.14 \\
\hline PD BB 17 & $06 / 05 / 2017$ & 35 & (236) & NDS & 53.580012 & 63.971686 & 263 & & trawl & 7.15 & 33.78 \\
\hline PD BB 17 & $05 / 05 / 2017$ & $36^{*}$ & (228) & SI & 53.733348 & 64.530011 & 133 & $\mathrm{x}$ & trawl & 7.96 & 33.57 \\
\hline PD BB 17 & $26 / 04 / 2017$ & 39 & $(79)$ & TDF & 54.233338 & 66.516677 & 53 & & trawl & 9.29 & 32.84 \\
\hline PD BB 17 & $25 / 04 / 2017$ & 40 & $(58)$ & TDF & 53.966686 & 67.016667 & 49 & & trawl & 9.59 & 32.87 \\
\hline PD BB 17 & $10 / 05 / 2017$ & 43 & (328) & MPA NII & 54.621679 & 61.460009 & 392 & $\mathrm{x}$ & trawl & na & na \\
\hline
\end{tabular}

Dead specimens also reported by Margolin et al. (2014) on the west and NW slopes of Burdwood Bank. Depth range: $75-1137 \mathrm{~m}$.

Remarks. Specimens were encrusted with bryozoans, stylasterids, serpulids, sponges (several species), brachiopods, and stalked barnacles and were found settled on pebbles (also encrusted by bryozoans, serpulids and stylasterids) and on other corals such as Balanophyllia malouinensis, Flabellum curvatum and $F$. areum (Figs 4, 5). The species was recorded at two stations inside Namuncurá I (between 177 and $196 \mathrm{~m}$ ), but it was often found in deeper areas, including Na- muncurá II. This was the most frequently recorded species of the present study, recorded at 15 of the 19 sites with presence of Scleractinia). Depth range recorded from the present study: $177-1000 \mathrm{~m}$.

Family Caryophyllidae Dana, 1846

Genus Caryophyllia Lamarck, 1801

Caryophyllia squiresi Cairns, 1982

(Figs 2C, 3E, F)

Material examined. BBB 2016: St. 13 (172) 3 specimens, St. 18 (266) 27 specimens, St. 18 (267) 6 specimens, St. 21 (239) 6 specimens, St. 25 (37) 2 specimens. PD BB 2017: St. 13 (103) 9 specimens, St. 14 (118) 2 specimens, St. 31 (269) 24 specimens, St. 34 


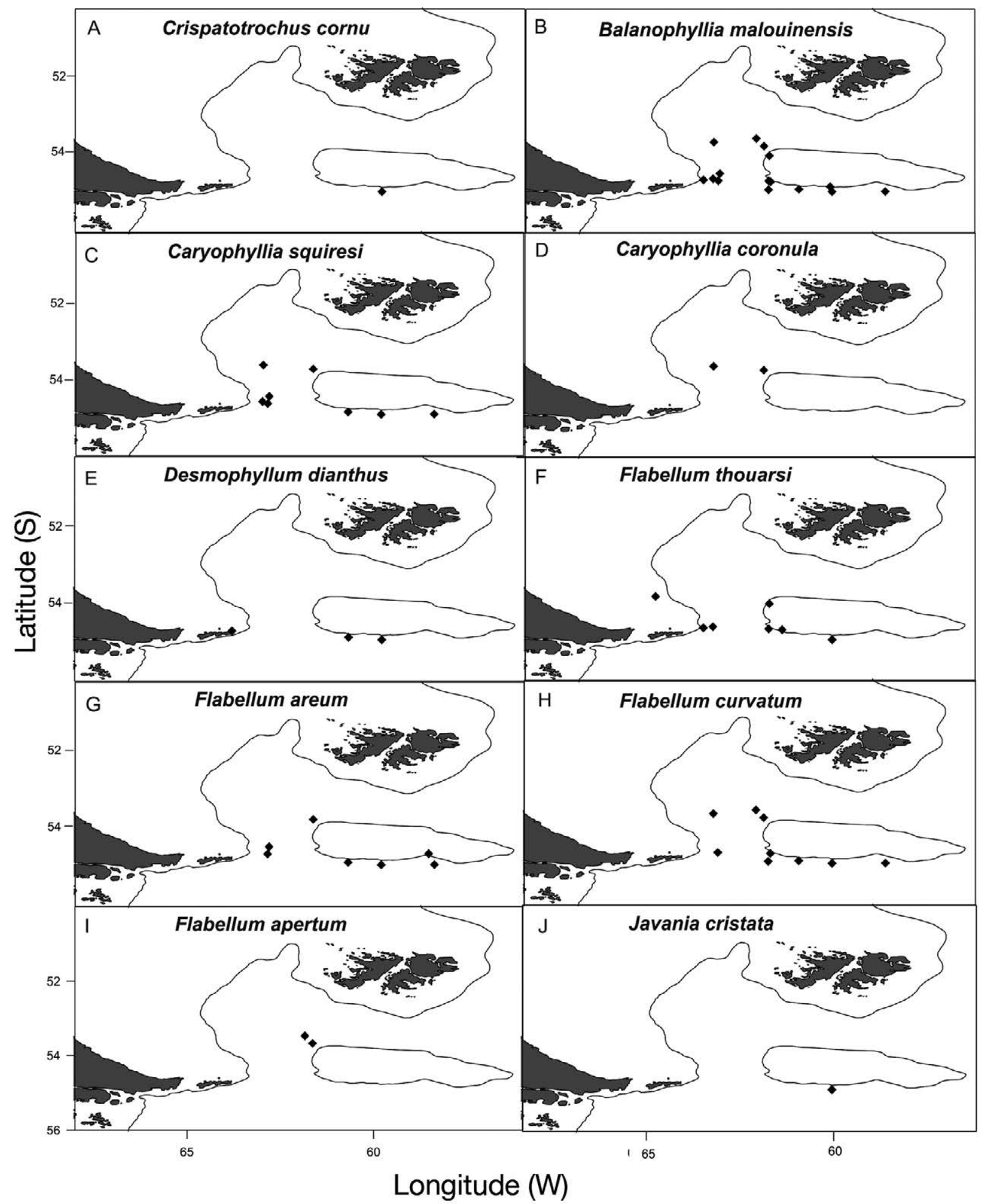

Fig. 2. - Distribution of the species of stony corals recorded in the present study. A, Crispatotrochus cornu; B, Balanophyllia malouinensis; C, Caryophyllia squiresi; D, Caryophyllia coronula; E, Desmophyllum dianthus; F, Flabellum thouarsi; G, Flabellum areum; H, Flabellum curvatum; I, Flabellum apertum; J, Javania cristata.

(249) 18 specimens (MACN-In 41677, MACN-In 41678, MACNIn 41679, MACN-In 41680, MACN-In 41681, MACN-In 41682, MACN-In 41683, MACN-In 41684, MACN-In 41685).

Main measurements. $\mathrm{CH}$ ranged between 9 and 38 $\mathrm{mm}$, CD between $10 \times 10 \mathrm{~mm}$ and $13 \times 15 \mathrm{~mm}$ and PD was about $3 \mathrm{~mm}$.
Distribution. Off Tierra del Fuego and Malvinas (Falkland) Islands at 406-659 m, recent records extended its range slightly north $\left(42^{\circ} \mathrm{S}\right)$ and expanded its bathymetric range (Cairns and Polonio 2013). Depth range: $158-1629 \mathrm{~m}$. 
Remarks. Some individuals were settled on Balanophyllia malouinensis. This species was recorded in eight sites, on the Burdwood Bank NW slope, in Namuncurá II and in the Neighbouring Deep Region. Depth range recorded in the present study: $451-785 \mathrm{~m}$.

Caryophyllia coronula Cairns and Polonio, 2013 (Figs 2D, 3C, D)

Material examined. PD BB 2017: St. 31 (269) 2 specimens, St. 34 (249) 1 specimen. (MACN-In 41675, MACN-In 41676).

Main measurements. $\mathrm{CH}$ between 14.5 and $32 \mathrm{~mm}$, CD between $9.5 \times 9.5 \mathrm{~mm}$ and $14.5 \times 15.5 \mathrm{~mm}$ and PD $3 \mathrm{~mm}$.

Distribution. Continental slope off Golfo San Jorge, Argentina, 797-1553 m (Cairns and Polonio 2013).

Remarks. The present finding represents the second mention of the species and extends the southern distribution limit to Burdwood Bank $\left(53.66^{\circ} \mathrm{S}\right.$ and $\left.61.63^{\circ} \mathrm{W}\right)$. It also extends the bathymetric range slightly to 516 m. This species was recorded at two sites outside Namuncurá I and II. Depth range recorded in the present study: 516-642 m.

\section{Genus Crispatotrochus Tenison-Woods, 1878 Crispatotrochus cornu (Moseley, 1881)} (Figs 2A, 3G, H)

Material examined. BBB 2016: St. 21 (239) 1 specimen (MACN-In 41674).

Main measurements. CH $13 \mathrm{~mm}, \mathrm{CD} 7.5 \times 8 \mathrm{~mm}$ and PD $2 \mathrm{~mm}$. Fascicular columella of twisted ribbons, pali absent.

Distribution. Continental slope off Argentina, 5861629 m (Cairns and Polonio 2013).

Remarks. This is a young specimen, similar to those described in Cairns (1979). It is encrusted by bryozoans. The present finding represents the southernmost record of the species, and updates the distribution limit to Burdwood Bank. This species was recorded at the MPA Namuncurá II. Depth recorded in the present study: $785 \mathrm{~m}$.

\section{Genus Desmophyllum Ehrenberg, 1834}

Desmophyllum dianthus (Esper, 1794) (Figs 2E, 3M, N, 4G)

Material examined. BBB 2016: St. 18 (266) 3 specimens, St. 18 (268) 1 specimen, St. 21 (239) 5 specimens, St. 21 (245) 1 specimen. PD BB 2017: St. 10 (349) 1 specimen (MACN-In 41686, MACN-In 41687, MACN-In 41688, MACN-In 41689, MACN-In 41690).

Main measurements. $\mathrm{CH}$ between 31 and $66 \mathrm{~mm}$, $\mathrm{CD}$ between $25 \times 34 \mathrm{~mm}$ and $28 \times 50 \mathrm{~mm}$.

Distribution. Cosmopolitan. In the southern hemisphere it was recorded in Australia, New Zealand,
Chile, Drake Passage and off South Georgias Is. (Cairns 1990), SW Atlantic Ocean, reaching $42^{\circ} \mathrm{S}$ in deep waters (Cairns and Polonio 2013, Schejter et al. 2015). Depth range: $8-2460 \mathrm{~m}$.

Remarks. Some individuals were settled on living and dead stylasterids, sometimes encrusted with bryozoans and colonized by polynoids and terebellids (polychaetes). One specimen was found settled on a naked rachis of an octocoral (Fig. 4G). Only dead specimens were previously recorded on the west slope of Burdwood Bank by Margolin et al. (2014). The present findings are the first record of living $D$. dianthus specimens in Namuncurá II, Burdwood Bank. Depth range recorded in the present study: 143-785 m.

Family Flabellidae Bourne, 1905

Genus Flabellum Lesson, 1831

Flabellum thouarsi Milne Edwards and Haime, 1848 (Figs 2F, 3K, L)

Material examined. BBB 2016: St. 12 (212) 5 specimens, St. 17 (282) 1 specimen, St. 21 (245) 1 specimen, St. 36 (306) 2 specimens, St. 36 (307) 7 specimens, St. $36(310) 2$ specimens. PD BB 2017: St. 13 (103) 14 specimens, St. 16 (131) 24 specimens, St. 36 (228) 26 specimens (MACN-In 41708, MACN-In 41709, MACNIn 41710, MACN-In 41711, MACN-In 41712, MACN-In 41713, MACN-In 41714).

Main measurements. $\mathrm{CH}$ range between 13 and 85 $\mathrm{mm}, \mathrm{CD}$ between $8 \times 11 \mathrm{~mm}$ and $14 \times 25 \mathrm{~mm}$ and PD between 3 and $4 \mathrm{~mm}$.

Distribution. Entire coast of Argentina from Río de la Plata to Tierra del Fuego, Malvinas (Falkland) Islands (Cairns and Polonio 2013). Depth range: 71$1513 \mathrm{~m}$

Remarks. Some individuals were found epibiotic on stylasterids. They were also found encrusted with bryozoans, spirorbids and other sandy polychaete tubes. Enlarged (old) individuals were also recorded. This species was previously recorded from Burdwood Bank (Cairns 1982, Schejter et al 2016a) and was now recorded in Namuncurá I and II. Depth range recorded in the present study: $133-767 \mathrm{~m}$.

Flabellum areum Cairns, 1982 (Figs 2G, 3S, T)

Material examined. BBB 2016. St. 13 (172) 47 specimens, St. 13 (175) 3 specimens, St. 18 (266) 28 specimens, St.18 (267) 9 specimens, St. 21 (239) 4 specimens, Station 25 (37) 1 specimen, St. 38 (39) 3 specimens. PD BB 2017. St. 14 (118) 100 specimens, St. 31 (269) 11 specimens (MACN-In 41693, MACN-In 41694, MACNIn 41695, MACN-In 41696, MACN-In 41697, MACN-In 41698, MACN-In 41699).

Main measurements. $\mathrm{CH}$ ranged between 12 and 45 $\mathrm{mm}, \mathrm{CD}$ between $10 \times 7.5 \mathrm{~mm}$ and $17 \times 21 \mathrm{~mm}$, and PD between 3 and $4 \mathrm{~mm}$.

Distribution. Between $38^{\circ} \mathrm{S}$ and the Malvinas (Falkland) Islands, beyond the shelf break, near Staten 


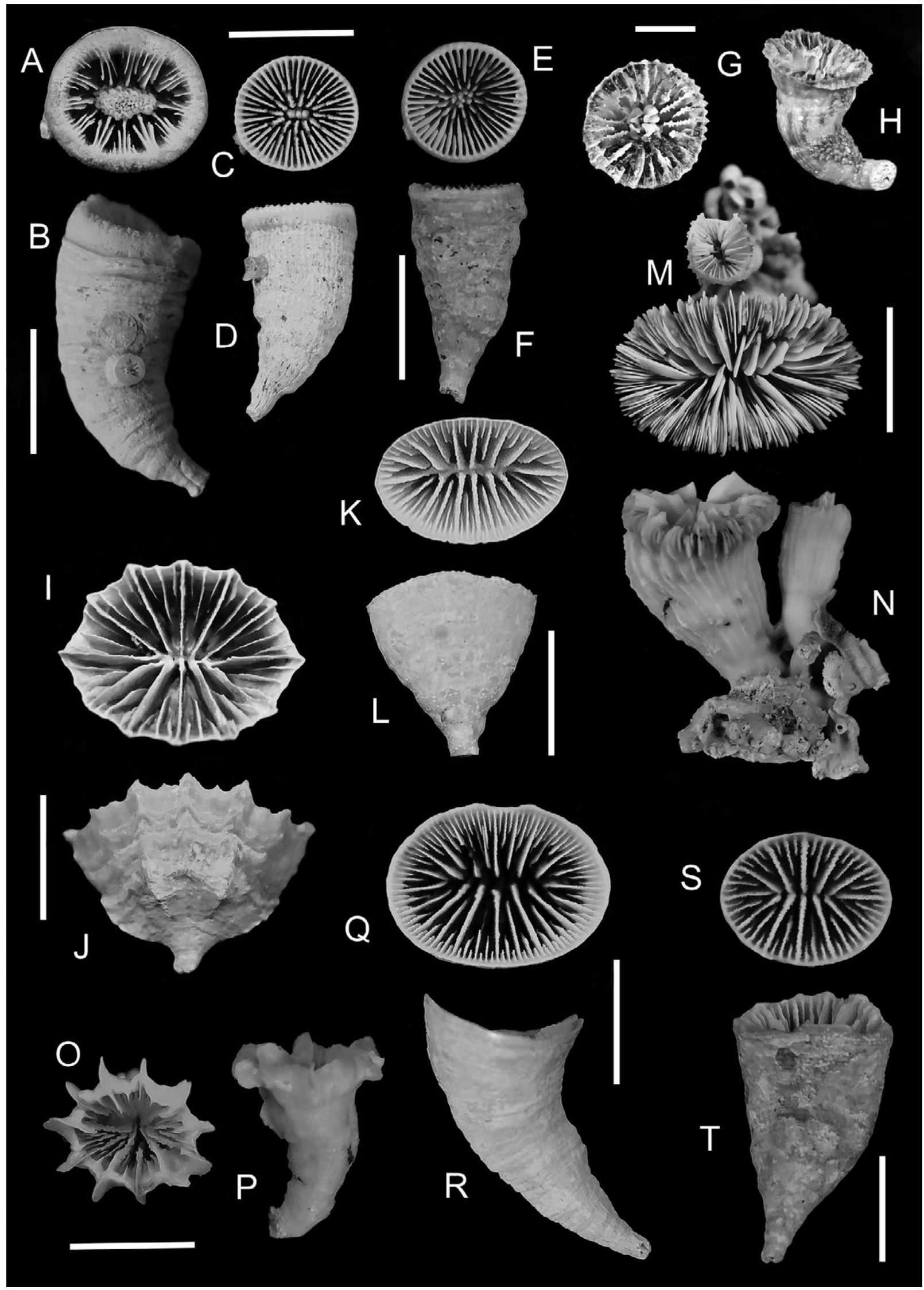

Fig. 3. - Scleractinia recorded in the present study. A, B, Balanophyllia malouinensis, scale $20 \mathrm{~mm}$; C, D, Caryophyllia coronula, scale 15 $\mathrm{mm}$; E, F, C. squiresi, scale $18 \mathrm{~mm}$; G, H, Crispatotrochus cornu, scale $3.5 \mathrm{~mm}$; I, J, Flabellum apertum, scale $13 \mathrm{~mm}$; K, L, F. thouarsi, scale $23 \mathrm{~mm} ; \mathrm{M}, \mathrm{N}$, Desmophyllum dianthus, scale $25 \mathrm{~mm}$; O, P, Javania cristata, scale $14 \mathrm{~mm}$; Q, R, F. curvatum, scale $12 \mathrm{~mm} ; \mathrm{S}, \mathrm{T}, F$. areum, scale $12 \mathrm{~mm}$. 
Island and SE slope of Burdwood Bank (Cairns 1982, Cairns and Polonio 2013); Antarctica, 64 ${ }^{\circ} \mathrm{S}$ (Schejter et al. 2016c). Depth range: $218-2229 \mathrm{~m}$.

Remarks. Some individuals were found settled on pebbles and stylasterids encrusted with serpulids. The species was found as a basibiont of Balanophyllia malouinensis. The species was recorded at seven sites, including Namuncurá I and II. The SE of Burdwood Bank is the type locality for this species. Depth range recorded from the present study: 135-681 m.

Flabellum curvatum Moseley, 1881 (Figs 2H, 3Q, R)

Material examined. BBB 2016. St. 21 (239) 10 specimens, St. 18 (267) 5 specimens, St. 13 (175) 11 specimens, St. 13 (172) 11 living specimens, St. 16 (334) 1 specimen, St. 25 (37) 1 specimen. PD BB 2017. St. 43 (326) 1 specimen, St. 31 (269) 495 specimens, St. 33 (256) 58 specimens, St. 34 (249) 98 specimens (MACN-In 41700, MACN-In 41701, MACN-In 41702, MACN-In 41703, MACN-In 41704, MACN-In 41705, MACN-In 41706, MACN-In 41707).

Main measurements. $\mathrm{CH}$ between 11 and $58 \mathrm{~mm}$, CD between $8.5 \times 11 \mathrm{~mm}$ and $21 \times 30 \mathrm{~mm}$, and PD between 3.5 and $4 \mathrm{~mm}$.

Distribution. Coast of Argentina from Río de la Plata to Tierra del Fuego, Malvinas (Falkland) Islands, South Georgias Is. and southern Chile (Cairns 1982, Cairns and Polonio 2013). Depth range: 115-1620 m.

Remarks. Some juveniles were found settled on adults of the same species or pebbles. Dead specimens may be a substrate of octocorals (Fig. 5). This species was found at nine sites, including Namuncurá II, and was the second most frequently recorded species of the present study, after B. malouinensis. Depth range recorded from the present study: 392$1000 \mathrm{~m}$

Flabellum (Ulocyathus) apertum Moseley, 1876 (Figs 2I, 3I, J)

Material examined. BBB 2017. St. 31 (269) 41 specimens, St. 33 (256) 1 specimen (MACN-In 41691, MACN-In 41692).

Main measurements. $\mathrm{CH}$ between 10 and $26.5 \mathrm{~mm}$, CD between $13 \times 17 \mathrm{~mm}$ and $17 \times 37 \mathrm{~mm}$, and PD between 2.5 and $3 \mathrm{~mm}$.

Distribution. Circum-sub-Antarctic, including off Prince Edward islands; Hjort Seamount; Macquire Ridge; off Chile; off Malvinas (Falkland) Islands; Malvinas Plateau; off southern Brazil; off southern New Zealand. Depth range: 220-1500 m (Cairns 1982).

Remarks. This species was already recorded for Burdwood Bank. In the present study it was recorded at two sites, only outside the MPAs, at the NW of Burdwood Bank. Depth range recorded from the present study: 269-595 m.
Genus Javania Duncan, 1876

Javania cristata Cairns and Polonio, 2013

(Figs 2J, 3O, P)

Material examined. BBB 2016. St. 21 (239) 11 specimens (MACNIn 41715).

Main measurements. $\mathrm{CH}$ between 24 and $30 \mathrm{~mm}$, CD between $12 \times 12 \mathrm{~mm}$ and $16 \times 15 \mathrm{~mm}$, and PD between 2 and $2.5 \mathrm{~mm}$. Living specimens had a bright orange to pink coloration visible through the translucent and delicate theca.

Distribution. Continental slope off central Argentina and Burdwood Bank (Cairns 1982, Cairns and Polonio 2013).

Remarks. Cairns and Polonio (2013) recorded and described this species off Argentinean waters, at $43.981^{\circ} \mathrm{S}$, and mentioned that it was the same species previously identified as $J$. cailleti on Burdwood Bank by Cairns (1982). In the present study we added new and recent records of this species in $\mathrm{Na}-$ muncurá II. Depth range recorded from the present study: $239 \mathrm{~m}$.

\section{Scleractinians as a substrate for other organisms}

Living specimens were found to host juveniles at early stages, as recorded for Balanophyllia malouinensis (present study) and for several species of Flabellum by Cairns (1982) (and present study). Stalked barnacles, brachiopods, polychaete tubes of at least three species, stylasterids, sponges and some bryozoan colonies were found epibiotic on living corals (Fig. 4). Pebbles and rocks were the most frequent settlement substrates used by stony corals, although living and dead stylasterid corals, dead gastropod shells and even naked rachises of octocorals were recorded (Fig. 4). Dead corals were found to be used as a settlement substrate by several sponges, bryozoans, tubicolous polychaetes and other corals (Fig. 5). Specifically, we found that stony corals were used as a substrate by the sponges Latrunculia sp. and Antho (Plocamia) bremecae Schejter, Ríos and Cristobo 2017, and by some other sponges belonging to the orders Myxillida and Suberitida. In the particular case of $A$. (P.) bremecae, we found our specimens on the west slope of Burdwood Bank with the typical described habitus, which is epibiotic on dead scleractinian skeletons (Schejter et al. 2017b). Among the soft corals, Alcyonium sp., Bayergorgia vermidoma and several Primnoidae species were also growing on dead scleractinian skeletons. Hydrozoans, bryozoans and tubes of polychaetes (spirorbids, serpulids, terebellids, polynoids and sabellarids) were also recorded growing attached to dead corals.

\section{Scleractinia richness in the study area}

The order of species richness recorded in the sub-areas in the present study was Namuncurá II $>$ Neighbouring Deep Region and Burdwood Bank 


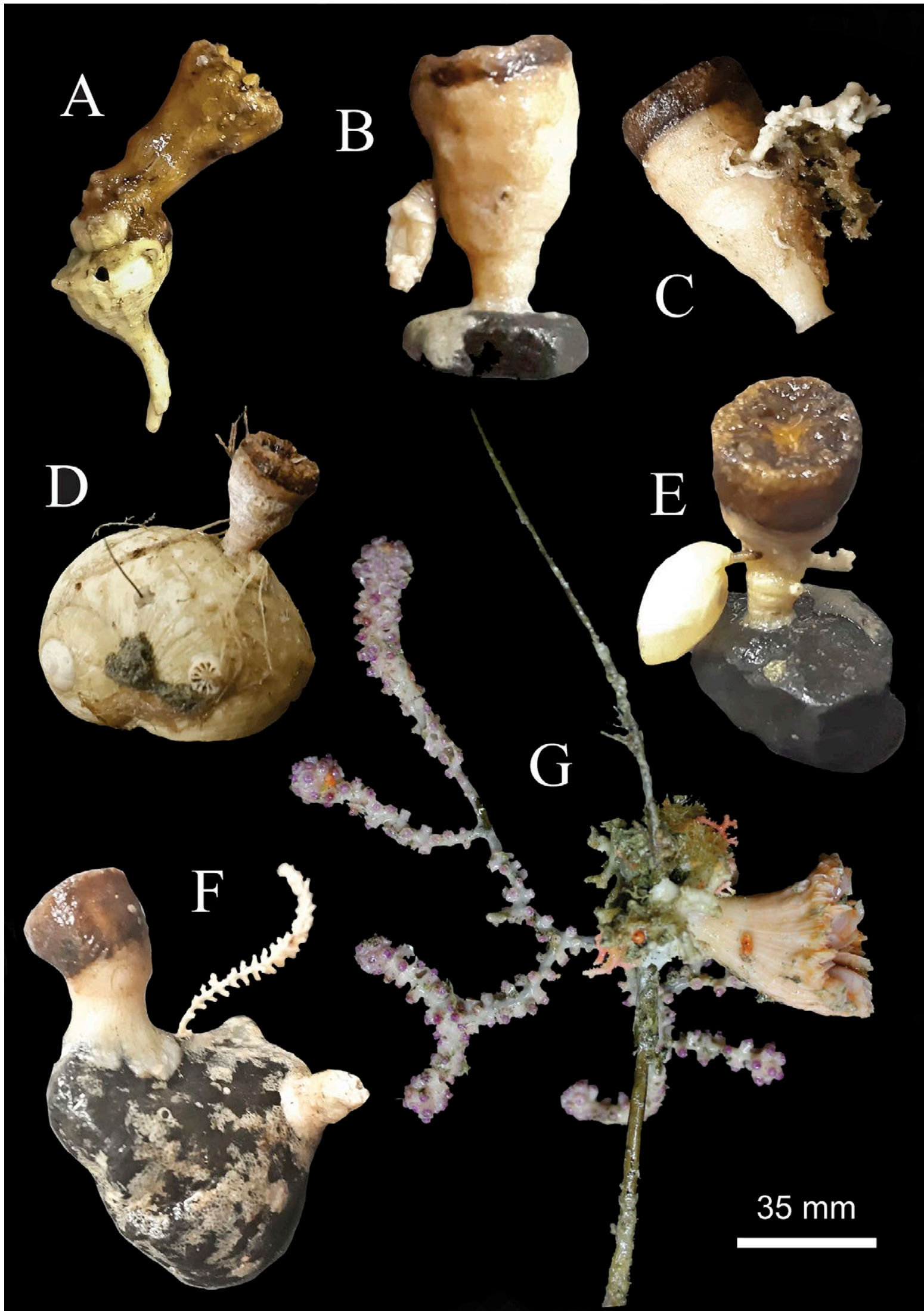

Fig. 4. - Living specimens of stony corals with associated organisms. A, Balanophyllia malouinensis epibiotic on a dead shell of Muricidae; $\mathrm{B}, B$. malouinensis on a pebble with an epibiotic stalked barnacle; $\mathrm{C}, B$. malouinensis with epibiotic byozoans, serpulids and sponges; D, $B$. malouinensis epibiotic on a dead shell of Naticidae; E, B. malouinensis on a pebble with an epibiotic brachiopod Lyothyrella uva and bryozoans; F, B. malouinensis on a rock, sharing the substrate with bryozoans and octocorals; G, Desmophyllum dianthus epibiotic on the octocoral Bayergorgia vermidoma. Small stylasterid colonies and hydrozoans are also growing attached to a naked portion of the octocoral. 


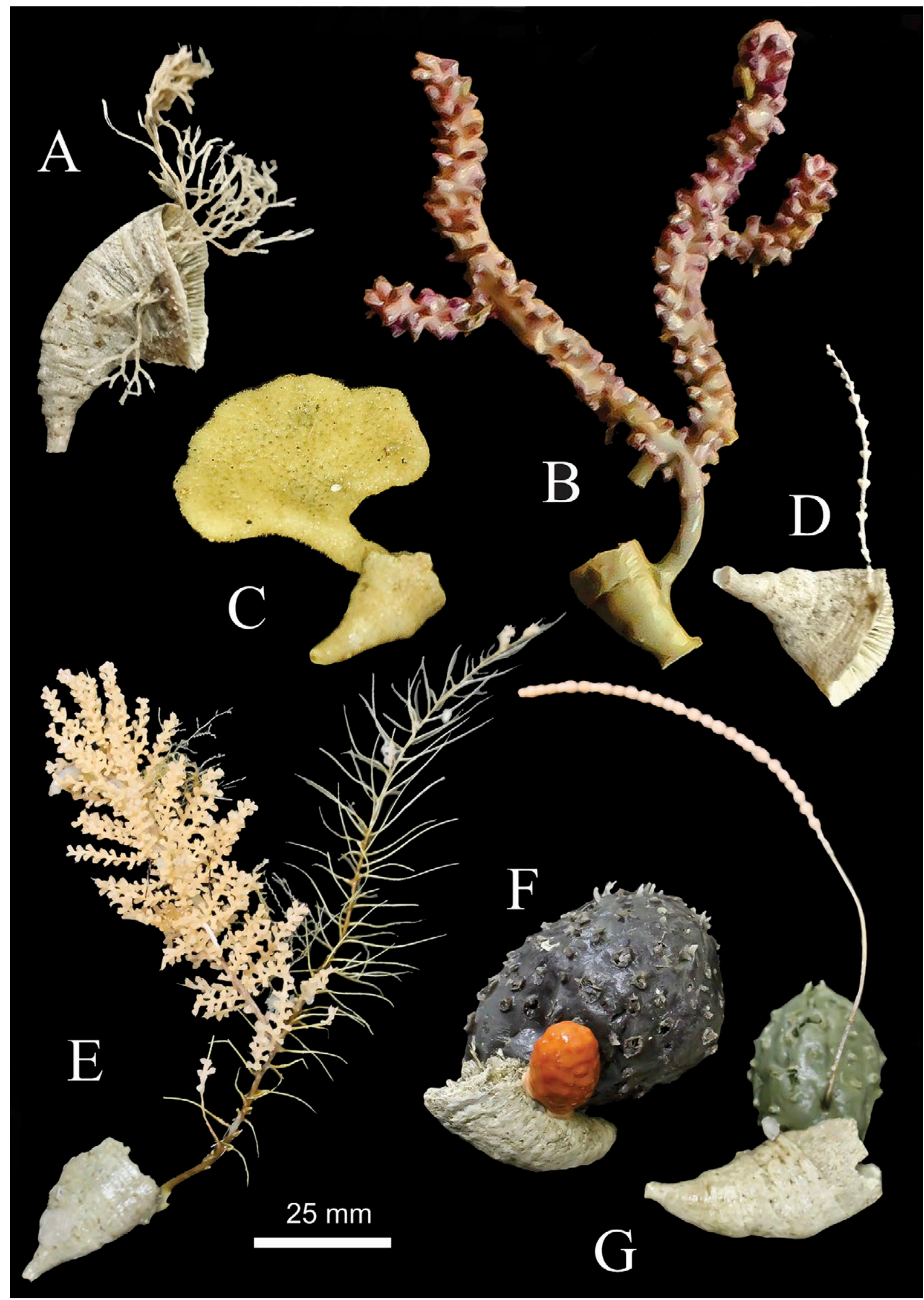

Fig. 5. - Dead scleractinians as a substrate for other organisms. A, bryozoa on Flabellum sp.; B, the octocoral Bayergorgia vermidoma on Balanophyllia malouinensis; C, the sponge Antho (Plocamia) bremecae on Flabellum sp.; D, the octocoral Convexella magelhaenica on Flabellum sp.; E, primnoid colony on Flabellum sp.; F. the sponge Latrunculia sp. and the octocoral Alcyonium sp. on Flabellum sp.; G, the sponge Latrunculia sp. and a primnoid colony on Flabellum sp. 
Table 2. - Recorded stony coral species at the different sub-areas. TDF: Tierra del Fuego; SI: Staten Island; NDR: Neighboring Deep Region; MPA NI: Marine Protected Area Namuncurá I; MPA NII: Marine Protected Area Namuncurá II; BBS: NW slope of Burdwood bank

\begin{tabular}{|c|c|c|c|c|}
\hline Sub-area & Present study & $\begin{array}{l}\text { Richness } \\
\text { Other Records }\end{array}$ & Total & Species \\
\hline $\mathrm{TDF}$ & 0 & 5 & 5 & $\begin{array}{c}\text { Sphenotrochus (Sphenotrochus) gardineri, Flabellum curvatum, } F . \text { thouarsi, } F \text {. } \\
\text { impensum, Balanophyllia malouinensis }\end{array}$ \\
\hline SI & 2 & 4 & 6 & $\begin{array}{c}\text { Sphenotrochus (Sphenotrochus) gardineri, Desmophyllum dianthus, Flabellum } \\
\text { thouarsi, F. areum, F. curvatum, Balanophyllia malouinensis. }\end{array}$ \\
\hline NDR & 6 & 0 & 6 & $\begin{array}{c}\text { Caryophyllia squiresi, C. coronula, Flabellum thouarsi, F. areum, F. curvatum, } \\
\text { Balanophyllia malouinensis }\end{array}$ \\
\hline MPA NI & 3 & 0 & 3 & Flabellum thouarsi, F. areum, Balanophyllia malouinensis \\
\hline MPA NII & 8 & 1 & 9 & $\begin{array}{c}\text { Flabellum thouarsi, } F \text {. areum, F. curvatum, Desmophyllum dianthus, } \\
\text { Caryophyllia squiresi, Crispatotrochus cornu, Javania cristata, Fungiacyathus } \\
\text { (Bathyactis) marenzelleri, Balanophyllia malouinensis }\end{array}$ \\
\hline BBS & 6 & 1 & 7 & $\begin{array}{c}\text { Flabellum areum, } F . \text { curvatum, } F \text {. apertum, Caryophyllia squiresi, } C . \text { coronula, } \\
\text { Truncatoflabellum truncum, Balanophyllia malouinensis }\end{array}$ \\
\hline
\end{tabular}

NW slope $>$ Namuncurá I $>$ Staten Island $>$ Tierra del Fuego shelf waters (Table 2). The group Namuncurá II + Burdwood Bank NW slope harboured all 10 species recorded in this study, many of them representing updates in the distributional ranges of the species, as mentioned in the previous sub-section. Additionally, other two species were previously recorded in deep areas of the slope of Burdwood Bank by Cairns (1982): Truncatoflabellum truncum (Cairns, 1982), recorded at $591 \mathrm{~m}$ depth at $53.142^{\circ} \mathrm{S}$ and $59.6^{\circ} \mathrm{W}$ during the expedition of the USNS Eltanin in 1962; and Fungiacyathus (Bathyactis) marenzelleri (Vaughan, 1906), recorded at $3578 \mathrm{~m}$ depth at $55.275^{\circ} \mathrm{S}$ and $58.942^{\circ} \mathrm{W}$ (currently, inside Namuncurá II) during the same cruise (see Cairns 1982). Another important sub-area in terms of stony coral richness was the Neighbouring Deep Region, with six recorded species (Table 2). No other species were recorded from the literature in this sub-area. Namuncurá I had only three species of stony corals (B. malouinensis, $F$. thouarsi and $F$. curvatum), of which only $B$. malouinensis was previously recorded here, more than 50 years ago (at $124 \mathrm{~m}$ depth at $54.65^{\circ} \mathrm{S}$ and $57.175^{\circ} \mathrm{W}$ during the USNS Eltanin cruise in 1966; see Cairns 1982). In the Staten Island sub-area we recorded Desmophyllum dianthus in coastal waters and $F$. thouarsi in northern deeper waters. However, four other species (Table 2) have been recorded in the past according to Cairns (1982), although they were reported more than 50 years ago during the expeditions of the RV Vema and the USNS Eltanin, and one record was also obtained from the RV Walther Herwig in 1971. No stony corals were reported in the present study in the Tierra del Fuego sub-area. However, five species $[S$. $(S)$. gardineri, $F$. thouarsi, $F$. areum, $F$. curvatum and $B$. malouinensis] were reported by Cairns (1982) from old expeditions and recently also Flabellum (Flabellum) impensum Squires, 1962, a species previously known only from Antarctic waters, was also recorded in shelf waters off Tierra del Fuego by Schejter and Bremec (2015). The absence of stony corals in this sub-area in the present study is probably related to the shallow waters, the oceanographic conditions in these areas (Table 1) and the fact that only five stations were sampled (see Fig. 1).

\section{DISCUSSION}

Of the 21 scleractinian species currently recorded from Argentinean waters (see Cairns 1982, Cairns and Polonio 2013, Schejter and Bremec 2015), we here reported about half of the total richness known. Considering the total extension of the Argentine continental shelf, the presence of such a high number of species in this small area highlights the importance of the order Scleractinia on Burdwood Bank and its neighbouring region, including both Namuncurá I and II. Biogeographic trends of the sampled species showed that, with the exceptions of Desmophyllum dianthus, considered a cosmopolitan species, and Flabellum areum, which is mainly a circum-sub-Antarctic species (Cairns 1982) with a southern extension into the cold Antarctic waters of the Western Peninsula (Schejter et al. 2016b), the remaining seven species recorded here are probably exclusive to the cold temperate waters of Argentina, essentially to the Atlantic portion of the Magellanic region. Balanophyllia malouinensis, already known from the Burdwood Bank/Malvinas (Falkland) region, was the most frequently recorded species in the present study. The detailed information presented in this study complement the exhaustive revision of Scleractinia made by Cairns and Polonio (2013) for a northern area on the slope of the Argentinean Continental shelf between approximately 41.9 and $47.5^{\circ} \mathrm{S}$.

The majority of the previous records of stony corals in the Burdwood Bank region were obtained about 50 years ago (or even more) during the expeditions of the USNS Eltanin in 1961 and 1966, the RV Vemma in 1958-62 and the RV Walther Herwig in 1971, and also during the expedition of the RSS William Scoresby from 1926 to 1933 (Cairns 1982). The only exceptions are the recent findings of dead skeletons (and some living specimens) of Flabellum curvatum, Desmophyllum dianthus and Balanophyllia malouinensis during US Antarctic Expeditions performed in 2008 and 2011, at the west of Burdwood Bank, published by Margolin et al. (2014). Four other stony coral species have been previously recorded in the region comprised in the present study, although they were not recorded currently by us: Sphenotrochus (S.) gardineri, Truncatoflabellum truncum and Fungiacyathus marenzelleri (Cairns 1982) and Flabellum (F.) impensum (Schejter and 
Bremec 2015). The total richness of the study area totals 14 species of the 21 currently recorded for Argentina, which represents $2 / 3$ of the total biodiversity. The study area is undoubtedly a very rich area, considering that Schejter et al. (2016c), from a similar number of stations (47), recorded only six scleractinian species in the Antarctic Peninsula and South Orkney Islands using the same sample devices in the same research vessel, and Cairns and Polonio (2013) recorded the same richness (14 species) in a much bigger area in the Argentinean shelf break, from more than 120 deep-sea stations.

The majority of the recorded species extended their known distributional ranges with the present data. Also, we report for the second time after its original description the species Caryophyllia coronula, thus extending its distribution limit southwards. In light of the present findings, we recorded the presence of several stony corals after about 50 years without data, upgrading the latitudinal and bathymetric ranges of many of them, and providing useful evidence on species composition of the cold-water coral habitats where octocorals are usually the main components. According to Schejter et al. (2018a), the benthic communities at stations 13 , 18,40 and 43 could be considered coral gardens, while at station 33 a sea pen stand was recorded (see also Schejter et al. 2018b). Additionally, while the benthic community at station 30 was characterized by a high biomass of sponges (a sponge aggregation area), a high biomass of cnidarians was recorded at station 31 (NW slope of Burdwood Bank). Scleractinians were also noted as important components of the coral gardens observed by Auscavitch and Waller (2017) at the west of Burdwood Bank (the region mentioned as the Neighbouring Deep Region in the present study). Considering that the species inventory of this region is currently in progress and will be available in the near future, it would be desirable for future research cruises expected from the development of the management plan of both MPAs to provide submarine images and a complete characterization of these habitats, including sediment types, sedimentation rates and updated oceanographic information, in order to complement the data on these highly biodiverse habitats.

From a total of 48 sampled sites, stony corals were recorded in only 3 stations located inside Namuncurá I (out of 20 sampled sites in this sub-area). The natural distribution of the cold-water scleractinian species, usually living deeper than $200 \mathrm{~m}$, is probably the main reason for the low frequency recorded (see Table 1). On the other hand, the finding of scleractinians at all the sampled stations in the southern slope of Burdwood Bank (8 stations) as components of coral gardens and other marine animal forests (Schejter et al. 2018a) partially supported the proposal for the creation of the new MPA Namuncurá II in 2018 (Argentina, National Law 27490) (FCMPAI 2018). However, the NW slope of the bank is also home to several species of stony corals, living in an area where large biomasses of sea pens and cnidarians were recorded (Schejter et al. 2018a, b). Both scleractinians and sea pens are among the indicator taxa of Vulnerable Marine Ecosystems, habitats having particular characteristics that makes them very sensitive to anthropogenic disturbance and that are worldwide protected (CCRVMA 2009, FAO 2009). Vulnerable Marine Ecosystems were recently recorded by Schejter et al. (2018a) in Namuncurá II but also in the Burdwood Bank NW slope sub-area. Considering that fishing activities are allowed outside the MPAs studied here, special monitoring should be considered for the non-protected slopes of Burdwood Bank in order to preserve these highly biodiverse sites. Fortunately, fishing activities have been reduced in part of the study area since 2008 (see Falabella et al. 2017).

The majority of the records and species (from 15 sites) were found on the slope of Burdwood Bank, in Namuncurá II, but they were also found on the NW slope of the bank (in total ten recorded species + two from bibliographic data; see Table 2) in neighbouring regions. Namuncurá II thus harbours the majority of the cold-water coral species. The rich waters derived from the Antarctic Circumpolar Drift that flow around the Burdwood Bank NW slope (see Table 1 for temperature and salinity measurements at the sampled stations, and Piola and Gordon 1989 and Guerrero et al. 1999 for detailed information) provide nutrients for the primary production (Bértola et al. 2018a, b). This phytoplankton community probably sustains the biodiversity found in the benthic ecosystem. Although scleractinian corals were not as abundant or large as other cnidarians (i.e. octocorals) or habitat-forming organisms recorded in the same region that constitute highly biodiverse habitats (Schejter et al. 2018a, Martin Sirito 2019), they were recorded as basibionts of a variety of organisms. Mainly dead skeletons of scleractinians also help to increase the richness of the region by providing a suitable settlement substrate for sessile species. Roberts and Hirschfield (2004) highlighted the ecological and commercial importance of cold-water coral habitats and mentioned the importance of measures aimed at managing threats, such as prohibiting any expansion of trawling into currently untrawled areas that potentially contain coral communities, closing currently trawled areas with known concentrations of corals and sponges, identifying and mapping the locations of all coral communities, and funding and initiating research to restore damaged deep-sea coral communities. Oil and gas exploration, seabed extraction, mining and cable laying are other potential threats to deep-sea coral communities.

In summary, this study provides updated data on stony coral richness in an area with previous records dating from more than 50 years ago. It also provides novel baseline evidence to support conservation efforts on marine benthic communities, demonstrating that stony corals are being mostly preserved by $\mathrm{Na}^{-}$ muncurá II, and highlighting the importance of the habitats on the slope of Burdwood Bank, beyond the $200 \mathrm{~m}$ isobath. This particular deep region has important fish habitats, Vulnerable Marine Ecosystems and marine animal forests mainly structured by cold-water coral communities (Falabella et al. 2017, Schejter et al. 2018a). 


\section{ACKNOWLEDGEMENTS}

We thank Marina Güller, Agustín Garese, Esteban Gaitán, Alejandro Puente Tapia, Ricardo Gonzalez and Ignacio Chiesa for help on board the RV Puerto Deseado during the sampling procedures. We are also deeply grateful to the scientific and navy crews of both cruises. The authors wish to especially thank Stephen Cairns for assessing and identifying some specimens. Agustina Mandiola helped with data from historical cruises in the region. Gustavo Lovrich, as a scientific and academic coordinator, supported and encouraged all the research projects dealing with the Namuncurá MPA, Burdwood Bank and the surrounding areas. We thank also Dr Ocaña and another anonymous reviewer for the useful suggestions on a previous version of this paper. This is INIDEP Contribution $\mathrm{N}^{\circ} 2177$. This is AMP Namuncurá Contribution $\mathrm{N}^{\circ} 25$.

The financial support for the cruises was provided by the Argentine Government and the Namuncurá MPA (National Law 26.875). The Instituto Nacional de Investigación y Desarrollo Pesquero (INIDEP) provided part of the equipment employed during the cruises. Laboratory supplies were partially financed by PICT 2013-0629.

\section{REFERENCES}

Auscavitch S.R., Waller R.G. 2017. Biogeographical patterns among deep sea megabenthic communities across the Drake Passage. Ant. Sci. 29: 531-543. https://doi.org/10.1017/S0954102017000256

Auster P.J., Gjerde K., Heupel E., et al. 2011. Definition and detection of vulnerable marine ecosystems on the high seas: problems with the "move-on" rule. ICES J. Mar. Sci. 68: 254-264. https://doi.org/10.1093/icesjms/fsa074

Bértola G., Olguín Salinas H., et al. 2018a. Estructura del plancton unicelular eucariota del AMP Namuncurá-banco Burdwood en primavera: conexiones con las adyacencias. X Jornadas Nacionales de Ciencias del Mar, Mar del Plata, Abstracts, p. 73.

Bértola G., Olguín Salinas H., et al. 2018b. Distribución espacial de Rhizosolenia crassa, iespecie clave del banco Burdwood? X Jornadas Nacionales de Ciencias del Mar, Mar del Plata, Abstracts, p. 74

Bremec C.S., Schejter L., Gaitán E., et al. 2017. Banco Burdwood, Islas Georgias del Sur y Antártida. In: Bremec C.S., Giberto D. (eds). Comunidades bentónicas en regiones de interés pesquero en Argentina. Instituto Nacional de Investigación y Desarrollo Pesquero, Mar del Plata, 77-92.

Buhl-Mortensen P., Buhl-Mortensen L., Purser A. 2017. Trophic Ecology and Habitat Provision in Cold-Water coral Ecosystems. In: Rossi S, Bramanti L, et al. (eds). Marine Animal Forests. The Ecology of Benthic Biodiversity Hotspots. Springer, Cham, $26 \mathrm{pp}$ https://doi.org/10.1007/978-3-319-17001-5_20-1

Cairns S.D. 1979. The deep-water Scleractinia of the Caribbean and adjacent waters. Studies on the fauna of Curacao and other Caribbean Islands 57, $341 \mathrm{pp}$

Cairns S.D. 1982. Antarctic and Subantarctic Scleractinia. Biology of the Antarctic Seas XI. Ant. Res. Ser. 34: 1-74.

Cairns S.D. 1990. Antarctic Scleractinia. Koenigstein: Koeltz Scientific Books, 78 pp.

Cairns S.D., Kitahara M. 2012. An illustrated key to the genera and subgenera of the recent azooxanthellate Scleractinia (Cnidaria, Anthozoa), with an attached glossary. Zookeys 227: 1-47.

Cairns S.D., Polonio V. 2013. New records of deep-water Scleractinia off Argentina and the Falkland Islands. Zootaxa 3691: 58-86.

https://doi.org/10.11646/zootaxa.3691.1.2

Cairns S.D., Haeusermann V., Forsterra G. 2005. A review of the Scleractinia (Cnidaria: Anthozoa) of Chile, with the description of two new species. Zootaxa 1018: 15-46. https://doi.org/10.11646/zootaxa.1018.1.2

CCRVMA. 2009. CCAMLR VME Taxa Identification Guide Version 2009. Commission for the Conservation of Antarctic Marine Living Resources, Hobart, Tasmania, Australia, 4 pp.

Falabella V., Caille G., Campagna C., et al. 2017. Area Marina Protegida Namuncurá - Banco Burdwood. In: Falabella V. (ed), Contribuciones para la línea de base y el plan de manejo, Jefatura de Gabinete de Ministros. Buenos Aires, Argentina, $76 \mathrm{pp}$.

FAO. 2009. International Guidelines for the Management of DeepSea fisheries in the High Seas. FAO, Rome. 92 pp.

Foro para la Conservación del Mar Patagónico y Áreas de Influencia (FCMPAI). 2018. Aportes para la consideración del Proyecto de Ley de Creación de las Áreas Marinas Protegidas: Yaganes y Namuncurá/Banco Burdwood II. Tech. Rep., 10 pp.

Fraysse C., Calcagno J., Pérez A.F. 2018. Asteroidea of the southern tip of South America, including Namuncurá Marine Protected Area at Burdwood Bank and Tierra del Fuego Province, Argentina. Pol. Biol. 12: 2423-2433. https://doi.org/10.1007/s00300-018-2377-3

Guerrero R.A., Baldoni A., Benavides H. 1999. Oceanographic conditions at the southern end of the Argentine continental slope. INIDEP Scient. Docs. 5: 7-22.

Güller M., Zelaya D.G. 2017. New insigths into the diversity of rissoids from sub-antarctic and antarctic waters (Gastropoda: Rissooidea). Pol. Biol. 40: 1923-1937. https://doi.org/10.1007/s00300-017-2108-1

López-Gappa J., Liuzzi M.G., Zelaya D.G. 2017. A new genus and species of cheilostome bryozoan associated with hermit crabs in the subantarctic Southwest Atlantic. Pol. Biol. 4: 733-741. https://doi.org/10.1007/s00300-017-2234-9

Margolin A.R., Robinson L.F., Burke A., et al. 2014. Temporal and spatial distributions of cold-water corals in the Drake Passage: insights from the last 35,000 years. Deep Sea Res. II 99: 237-248. https://doi.org/10.1016/j.dsr2.2013.06.008

Martin Sirito S. 2019. Fauna asociada a corales (Octocorallia) e hidroides (Hydrozoa) del Área Marina Protegida "Namuncurá" (Banco Burdwood) y zonas profundas adyacentes. Degree thesis, Universidad Nacional de Mar del Plata, 45 pp.

Piola A.R., Gordon A.L. 1989. Intermediate waters in the southwest South Atlantic. Deep Sea Res. 36: 1-16. https://doi.org/10.1016/0198-0149(89)90015-0

Portela J., Acosta J., Cristobo J., et al. 2012. Management Strategies to Limit the Impact of Bottom Trawling on VMEs in the High Seas of the SW Atlantic. In: Cruzado A. (ed). Mar. Ecosystem, InTech, pp. 199-228. https://doi.org/10.5772/34610

Roberts S., Hirshfield M. 2004. Deep-sea corals: out of sight, but no longer out of mind. Front. Ecol. Environ. 2: 123-130. https://doi.org/10.1890/1540-9295(2004)002[0123:DCOOSB] 2.0.CO;2

Schejter L., Bremec C. 2015. First record and range extension of the Antarctic coral Flabellum (Flabellum) impensum Squires, 1962 (Cnidaria: Scleractinia) in Argentinean coastal waters. Mar. Biod. Rec. 8: e104. https://doi.org/10.1017/S1755267215000858

Schejter L., Schwartz M., Bremec C.S. 2015. Registro del coral de piedra Desmophyllum dianthus (Esper, 1794) (Scleractinia, Caryophylliidae) en áreas del frente de talud del Mar Argentino. Rev. Invest. Des. Pesq. 26: 89-95.

Schejter L., Rimondino C., Chiesa I., et al. 2016a. Namuncurá Marine Protected Area: an oceanic hot spot of benthic biodiversity at Burdwood Bank, Argentina. Pol. Biol. 39: 2373-2386. https://doi.org/10.1007/s00300-016-1913-2

Schejter L., Padovani L., Veccia M.H. 2016b. Campaña al AMP Namuncurá - Banco Burdwood: Bentos. INIDEP Cruise Rep. 22/2016, 2+282 pp.

Schejter L., Bremec C.S., Cairns S.D. 2016c. Scleractinian corals recorded in the Argentinean Antarctic expeditions between 2012 and 2014, with comments on Flabellum (Flabellum) areum Cairns, 1982. Pol. Res. 35: 29762. https://doi.org/10.3402/polar.v35.29762

Schejter L., Martín J., Lovrich G. 2017a. Unveiling the submarine landscape of the Namuncurá Marine Protected Area, Burdwood Bank, SW Atlantic Ocean. Pan. Am. J. Aq. Sci. 12: 248-253.

Schejter L., Bertolino M., Calcinai B. 2017b. Description of Antho (Plocamia) bremecae sp. nov, and checklist of Microcionidae (Demospongiae: Poecilosclerida) from Burdwood Bank and neighboring areas, SW Atlantic Ocean. Zootaxa 4312: 580-594. https://doi.org/10.11646/zootaxa.4312.3.11 
Schejter L., Di Leva A., Gaitán E., et al. 2017c. Campaña de Investigación al Banco Burdwood. Buque Oceanográfico ARA "Puerto Deseado" - PD BB ABR 17. INIDEP Cruise Rep. 21/2017, $150 \mathrm{pp}$.

Schejter L., Genzano G., Gaitán E., et al. 2018a. Bosques animales marinos en el Atlántico Sudoccidental: el banco Burdwood, $54^{\circ}$ S. INIDEP Res. Rep. 38/2018, 12 pp.
Schejter L., Acuña F.H., Garese A., et al. 2018b. Sea pens (Cnidaria: Pennatulacea) from Argentine waters: new distributional records and first report of associated sea anemones. Pan. Am. J. Aq. Sci. 13: 292-301.

Zibrowius H. 1974. Révision du genre Javania et considérations générales sur les Flabellidae (Scleractiniaires). Bull. Inst. Ocean. 71: $1-48$. 